Nov. (1955).

17) Chemical Eng. March 215 (1957); June 201 (1957); Sept. 111 (1957).

18) Thermo-Spray Manual (Met. Eng. Co. Inc. カタログ) May. (1956).

19) A. V. Levy, Metal Progress, March 86 (1959).

20）長坂, 小野寺, 武井, 金属表面技術 10，355（1959）.

21）特許出願公告 昭 31-713.
22) F. E. King, Mat. and Methods, Oct. 112 (1952).

23) Jet Propulsion, March 306 (1957).

24) P. Fossen, Missiles and Rockets, Dec. 26 (1958).

25) Machinery, Jan. 122 (1959).

26) W. M. Stocker, Metal Working Production, 23, 2038 (1958).

27) $C \& E N$, Nov. 72 (1959).

28) J. F. Rice, Ind. Heating 216 (3) 554 (1959).

\title{
新耐熱材料, Devitroceramics
}

\section{1 ま えがき}

セラミックスは一般に多数の結晶粒子から構成されて拉り，近 似的にいえば; 微細な結晶を適当な方法で固めて成形し, 焼成し てつくられる。この際, 結晶粒子間に複雑な固相, 液相反応が招 こり, 結晶粒子間にガラス状物質が生じて接着剂の役目を果し, きわめて高い強度を発揮するよ5になる。しかし，このような製 造方法では折のずから原料あるいは成形方法等にもとつく制約の ために，たと公構成結晶の粒子を数 $\mu$ 以下の微粒とすること はきわめて困難であるし，製造過程中生ずる乾燥拉よび烧成収 縮による変形を避けることもむずかしい（最近，ルーカロクスの 名のもとにアルミナの超顕微鏡的な微結晶からなる耐熱材料が発 表されたが，原料の製造にきわめて特殊な方法がとられているよ らである)。

このようなセラミックスの一般的な製造過程を，まったく逆の 方向からこころみ，数々の新しい特徵を付与することに成功した のが、ここに紹介する新耐熱材料であって，その製造過程にガラス の失透 (Devitrification) 現象を利用するところから，われわれ はこれを Devitroceramics，略してデビトロセラム (Devitroceram）と呼ら゙ことにした。この新材料の製造は，まず特定の組 成範囲のガラスから出発して, その飴細工にも似た加工性を利用 し, 高い精度の成形加工を㨟こなったのちに, 適当な力法で処理 してガラスを失透させ，初めの形状を保ったままで微細な結晶の 集合体に変える。このような方法でつくられたセラミックスの内 部組織を調べると，るとのガラスの $90 \%$ 以上が結晶に変化し， また析出した結晶の組織はきわめて均質かつ微細で，結晶粒子の 大きさは $1 \mu$ あるいはとの数十分の一にも抑元られることがわ かった。

この新しい製造法によったセラミックス，すなわちデビトロセ ラムは従来のセラミックスとしての加工性の限界を突きやぶり， またガラスのるつ宿命的と思われる欠点, 脆弱性を補った上に, 電波に対して透明であり，また組成のえらびかたによっては熱膨 張俰数を零にも負化すすることがでさるため, 熱衝撃にもきわめ て強いので, 1957 年にアメリカではミサイル弾頭部などにも用 いられて、「鋼鉄より堅く、アルミニウムよりも軽い.......」とい

\section{境 野 照 雄*}

ろ謳い文句とともに, 一躍, 驚異の新材料として全世界に喧伝さ れたことは耳新しい。

このデビトロセラムは，当初アメリカのガラス製造会社である コーニングの Stookey1,2) によって手がけられ，パイロセラム (Pyroceram) 招よびフォトセラム (Fotoceram) の名称で発表さ れ，その用途も一般のセラミックスの範囲の他に，ボールベアリ ング, 理化学用器具, 化学工業用装置, その他電気絶縁性, 耐熱 性, 耐熱衝撃性等を必要とする，あらゆる科学，工業の分野に急 速な勢で拡まりつつあるが，いまから約 10 年以前に Stookey はすでに感光性ガラス ${ }^{3)}$ を造り出しており，ガラス中に分散して いる金，銀，銅等のイオンを紫外線照射によって還元し，適当な 熱処理によって凝集して結晶核を形成させたのち，それを中心と してガラスを結晶化させる機構については広範な研究をおこなっ ていたので，この新材料の製造法の完成もその自然な発展として 受取ることができる。

しかし, デビトロセラムの製造過程で, 均質な微結晶を析出さ せる方法は，その後，紫外線の照射を必要としない方向へ発展 し，結晶核生成物質として酸化チタン4)，酸化ジルコニウム占， フッ化物6)等の添加により，熱処理のみによるデビトロセラム製 造の研究がつぎつぎと発表され，筆者ら 雲母の組成を含むガラスが失透によって微結晶を急速に析出する ことを利用して、“マイカ”一ースポジウメン系デビトロセラムの 製造研究を拄こない，満足すべき結果を括さめている。

さらに最近，筆者ら ${ }^{8)}$ はバナジウムを含む一群の遥移元素を添 加することによってもガラスから極度に微細な結晶が析出するこ とを見出した。この方法によれば，鉄，ニッケル等のありふれた 元素を利用できるので，デビトロセラムの製造はいっそう容易に なるものと思われる。この場合, 加兄られた遷移元素自身は, か ならずしも結晶核を生成することなく，単に基儊ガラスの結晶核 生成を促進するだけの役割しか果していないのではないかと考兄 られ，その作用および機構については，きわめて興味ふかいもの がある。

\section{2 デビトロセラムに用いられる原ガラスに必要な性質}

ここで，どんな性質をむつガラスがデビトロセラムとして適当 であるか，また，その内のどんな点に問題があるか，簡単に述べ 
よう。まず第一に，ガラス状態で成形加工し，熱処理によって結 晶質のセラミックスに变光る方法は，Stookey ${ }^{1)}$ のそれ以前，た とえば 1951 年に, コーディエライト磁器の製造法として杉浦9 に特許が与えられている。ただし，この場合には結晶核生成を制 御することに考慮がはらわれていないから，結晶粒子の大きさは 数百 $\mu$ 程度に発達してしまう。

さて，デビトロセラム製造用のガラスに必要とされる性質を順 次かかげる。

（A）高温に特ける成形時に安定なガラス状態をたもち，かつ 加工に適した粘度と表面張力をもつこと:-一般のガラスは，で きるだけ結晶化の速度が小さくなるよう研究されて来たのである が，デビトロセラム用のガラスは，作業温度では安定なガラス状 態を，そして熱処理温度では高い結晶速度を要求されるので，お のずから化学組成淿種々の制約が加学られる。

（B） ガラスが表面失透を括こさないで，内部から一様に微細 な結晶を析出すること:一成形されたガラスの表面や内部に含ま れる気泡，異物等の界面では，他の部分にくらべて結晶核生成の 確率が高いから，結晶の析出が均等に㧍こなわれず，全体として 結晶核の数が十分に多くないと，結晶は粗大になる。したがっ て，微細で均質な結晶を析出させるためには，何らかの方法でガ ラスのあらゆる部分に多数の結晶核を一様に生成させなければな らない。

（C）ガラスから結晶集合体となる場合に，いちじるしい容積 変化をともなわないこと:一このことは加工精度を高くたもつた めにも，また熱処理操作を容易にするためにも必要な条件で，基 礎ガラス組成と析出結晶の種類によってきまる。

（D）結晶集合体がすぐれた物理的化学的諸性質をもつこと:以上の諸条件によって，基礎ガラスの性質が規定され，したがっ てその化学組成怙よび添加剤がさだまって来る。しかし，これら に適合するガラスや添加剤の研究は熱処理によっておこる諸現象 と深いつながりをもち，多くの未開拓の分野が残されている。

\section{3 ガラスの結晶化}

デビトロセラムをつくるもっとも重要な過程は，ガラスの熱処 理時に括ける結晶核生成を制御することであり，またデビトロセ ラムの製造法の特色も, 主としてこの点にあるとい方る。したが って，デビトロセラム研究の焦点も，いまのところ, 微細な結晶 を析出させるための適当な添加剤扣よび熱処理法の発見にある。 以下，それらを中心として，ガラスの結晶化の問題に関する最近 の諸研究を紹介しょ5。

\section{1 結晶核の生成}

ガラスのよ5な過冷却夜体から結晶集合体を生ずる場合に，そ の結唱組織の均質性や結晶粒子の大ささは，一般に, 結晶析出過程 の初期に生ずる結晶核の数とその分布に上って決まると考兄られ る。いまガラスを構成するイオンの種類とイオン半径などを均ら して近似的に扱 5 と，液相中に $i$ 個の原子からなる固相の $\mathrm{Emb}-$ ryo が生成することによる，その付近の自由エネルギーの変化， $\Delta F_{i}$ は次式によってあた只らるる100

$$
\Delta F_{i} / k T=A i^{2 / 3}+B i
$$

ただし， $A$ は Embryo の単位表面積あたりの界面自由エネルギ 一飞比例し，B界面を無視した場合の固相, 液相の自由エネル ギーの差に比例する量でめって， $k$ と $T$ はそれぞれ，ボルッマ

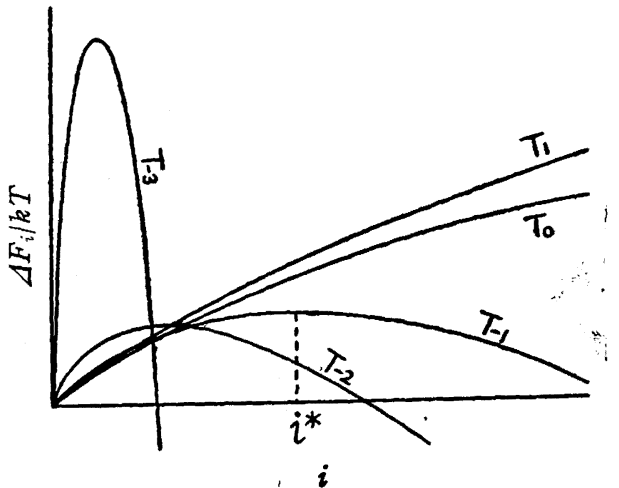

図 1 結晶核生成と自由エネルギーの変化

ン定数, 絶対温度をあらわす。この式にしたがって $i と \Delta F_{i} / k T$ の関係を示す曲線を描くと図 1 が得られる。眓中， $T_{0}$ は液相と 固相の自由エネルギーの差が零となる温度, すなわち両相の転移 温度を示し, したがって $T=T_{0}$ では $B=0$ となり，また $T \geqq T_{0}$ の温度範围では単調な增加曲線がえられる。これに反し, $T<T_{0}$ の温度範囲の過冷却状態では，B の值が負となるから，曲線は $T_{-1}, T_{-2}, T_{-3}$ 等のように, ある $i の$ 值に対して極大点をるつよ らになり，Embryo が発達して固相の結晶核を生ずるためには， これらの自由エネルギーの障壁を越觉る必要があることを示して いる。

このような場合に，成形されたガラスの表面では，同じく $i$ 個 の原子からつくられる Embryo の界面は，ガラス内部につくら れるそれにくらべて小さくてすむから，結晶核を生ずるための自 由エネルギーの障壁の高さは, ガラス内部より表面の方が低いこ とになり，結晶核生成の確率は高くなる。ガラス全体として結晶 核の数が十分に多くないと，個々の結晶は発達して粗大となり， また結晶が表面から析出し, 順次, 内部へ向って発達すると結晶 組織は不均質となる。

しかし，ガラスの内部に外来結晶核が一様に存在していれば， これらは前述のガラス表面と同様の条件を与えるから，結晶析出 は個々の結晶核を中心として始まり，かつ外来結晶核の数が十分 に多ければ，析出結晶は微細で，また大きさも揃い，均質で緻密 な結晶組織になる。また，外来結晶核を欠く場合でも，因1から わかるよ5に，過冷却温度範囲内で，たと兄ば平衡状態を $T_{-1}$ から $T_{-2}$ へ急激に変えることによって生ずる Athermal nucleation ${ }^{10)}$ を利用して，多数の結晶核を生成させることの可能性む 考兄られる。

\section{2 結晶化の方法}

ガラスの失透によって，微細な結晶を一様に析出させるために 考兄られる方法を整理すると表1のようになる。

表中，外来結晶核を利用する方法は，〈りか兄し述べたよう に，ガラス中に多数の外来結晶核を生成させる方法である。まず

表 1 結晶核生成を制御する方法（表 2 参照）

(I) 外来結晶核利用法

1. 金属結晶核を利用する

a. 放射線を照射する

b. Thermo-reducing agent 等を利用する

2. 酸化物結晶核を利用する

3. フッ化物乞の他の結晶核を利用する

(II) 無 核 法

1. Athermal nucleation 法

2. Spontaneous nucleation 促進法

a. 遥移元秦を利用する

b. その他の多原子価元器を利用する
(組成例 1)

(組成例 2)

(租成例 3)

(租成例 4)

（程成倒 5) 
表 2 デビトロセラムの組成例

\begin{tabular}{ccccc}
$(1)$ & $(2)$ & $(3)$ & $(4)$ & $(5)$ \\
\hline 80 & 88.9 & 69.8 & 51.9 & 71.5 \\
- & - & 3.0 & - & - \\
4 & - & 14.9 & 19.8 & 15.2 \\
- & - & - & 15.7 & - \\
1 & - & - & - & - \\
12.5 & 11.1 & 4.3 & 4.5 & 13.3 \\
- & - & 1.0 & - & - \\
2.5 & - & - & - & - \\
- & - & - & 8.1 & - \\
0.003 & - & - & - & - \\
- & 0.01 & - & - & - \\
- & - & 7.0 & - & - \\
- & - & - & - & 16.2 \\
0.03 & - & - & - & -
\end{tabular}

(1) Corning Glass 社, フォトセラム2)

(2) G.E. Rindone ${ }^{15}$ )

(3) Corning Glass 社, パイロセラムゅ)

(4) “Mica"'Spodumene 系デビトロセラム7)

(5) $\mathrm{Li}_{2} \mathrm{O} \cdot 2 \mathrm{SiO}_{2}-\mathrm{Li}_{2} \mathrm{O} \cdot \mathrm{Al}_{2} \mathrm{O}_{3} \cdot 4 \mathrm{SiO}_{3}$ 系デビトロセラム13)

Stookey は感光性ガラス ${ }^{3)}$ を発展させて $\mathrm{Li}_{2} \mathrm{O}-\mathrm{Al}_{2} \mathrm{O}_{3}-\mathrm{SiO}_{2}$ 系のガ ラス組成に，それぞれ金，銀，銅などの化合物の微量と，増感剂 として酸化セリウムを添加したガラスに対し，紫外線を照射して ガラス中の $\mathrm{Au}^{+}, \mathrm{Ag}^{+}, \mathrm{Cu}^{+}$などのイオンを光化学的に還元した のち，熱処理によってそれらを凝集させて微細な金属コロイドと し，結晶核として利用して，はじめてフォトセラムと称せられる 結晶質材料を造りあげた2)。金属イオンの光化学的な還元には, $\mathrm{X}$ 線，r線などる同じよ5に利用できることは Maurer ${ }^{11)}$ や森 谷ら ${ }^{12)}$ の研究によっても確かめられ, 金属コロイド粒子の大き さ，分布などが結晶化に与党る影響については田代ら ${ }^{19)}$ の報告が ある。その後, 光化学反応を用いず Thermo-reducing を利用す る方法が研究された ${ }^{14,15) 。 ~}$

他方，結晶核生成剤として酸化チタンが $\mathrm{Li}_{2} \mathrm{O}-\mathrm{Al}_{2} \mathrm{O}_{3}-\mathrm{SiO}_{2}$ 系, $\mathrm{MgO}-\mathrm{Al}_{2} \mathrm{O}_{3}-\mathrm{SiO}_{2}$ 系のガラスに有効であることが Stookey によ って見出され4), 田代らも酸化ジルコニウムを利用して， $\mathrm{Li}_{2} \mathrm{O}$ $\mathrm{MgO}-\mathrm{Al}_{2} \mathrm{O}_{3}-\mathrm{SiO}_{2}-\mathrm{P}_{2} \mathrm{O}_{5}$ 系ガラスから, 微細な結晶からなるデビ トロセラムを得ることに成功した ${ }^{16)}$ 。酸化物以外では Lungu ら が $\mathrm{R}_{2} \mathrm{O}-\mathrm{MgO}-\mathrm{SiO}_{2}$ 系などのガラスにフッ化物を加えの)また森谷 らはリシア，フッ素を含む雲母の組成を多量にスポジウメン組成 に加え ${ }^{7)}$, ともに微細で緻密な結晶性物質を得た。とくに森谷ら の場合には，試料中に雲母組成が $50 \mathrm{~mol} \%$ 以上も含まれ，した がって, 得られた結晶性物質の大半は雲母と思われる結晶で占め られているので，あはやこれを結晶核生成のための添加剤とよぶ には不適当かもしれない。しかし，スポジウメン組成に前述の雲 母組成を混ぜるにしたがって，ガラス中から析出する結晶は次第 に微細となり, 結晶析出の温度も低下する事実がたしかめられて いる。

このように, 外来結晶核を利用する方法は, きわめて多くの研 究者によって研究され, 種々の有効な方法が見出されているのに 反し，外来結晶核を用いずにガラスの Spontaneous nucleation を促進させる方法に関しては，わずかに田代の研究 ${ }^{24)}$ 以外に報告 が見られなかった。しかし最近, 森谷らは, $\mathrm{V}, \mathrm{Ni}$, 等の一群の 摡移元素を $\mathrm{Li}_{2} \mathrm{O} \cdot 2 \mathrm{SiO}_{2}-\mathrm{Li}_{2} \mathrm{O} \cdot \mathrm{Al}_{2} \mathrm{O}_{3} \cdot 4 \mathrm{SiO}_{2}$ 系ガラスに導入し, $1 \mu$ 程度の微結晶からなる均質な結晶性物質を得た ${ }^{17)}$ 。この場合には 析出結晶中に, 添加した遷移元素を含む結晶はX線解析によって 認められないし，またこれらを少量添加されたガラスが結晶しゃ すいとは考えられない。したがってこれらの添加物はガラス中
で外来結晶核を形成することなく，単にガラス成分自体の結晶核 生成(Spontaneous nucleation) を促進する作用を果したものと思 われる。抏そらく，これらの多原子価イオンは，それぞれガラス 中でも 2 種またはそれ以上の原子価のイオンとなって共存し，熱 処理にともなら温度変化によって，それらの平衡関係も変わるた め，共存する原子価の異なるイオンの間に価電子の受授がおうう われ，それが契機となってガラス成分の Spontaneous nucleation をひき抗こすのではないかと想像される。このような機構は遷移 元素以外の多原子価元素にも考えられるから，さらにそれを利用 することの可能性も目下検討されている。

\section{$3 \cdot 3$ 結晶化過 程}

ここで，デビトロセラムの製造工程をブロック・ダイアグラム であらわしてみると，図2のように，結晶化のための熱処理が 2 段階に分かれている。これは，原ガラスから最大限に結晶を析出 させ，安定な結晶質に変えるための最終的な熱処理温度が，原ガ

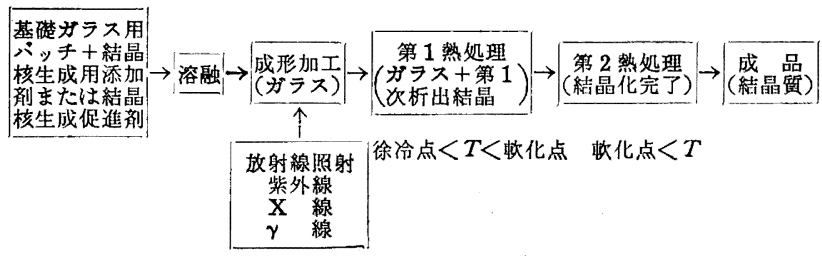

図 2 デビトロセラムの製造過程

ラスの軟化点より高いことに原因がある。したがって，成形され たガラス試料は，まず結晶核析出のためにイオンが再配列しらる 温度，すなわち原ガラスの徐冷点より高く，軟化点より低い温度 範囲で第 1 熱処理がおこなわれる。これによりガラス中に結晶核 が析出し，ひきつついて，この温度範囲で可能な結晶の析出が拉 こる。一般に，第 1 熱処理によって析出する結晶の量は原ガラス の $50 \%$ に満たず，大半はなおガラス質として残留するが，試料 の見かけの軟化温度は高くなるから，ひきつづいてガラス試料の

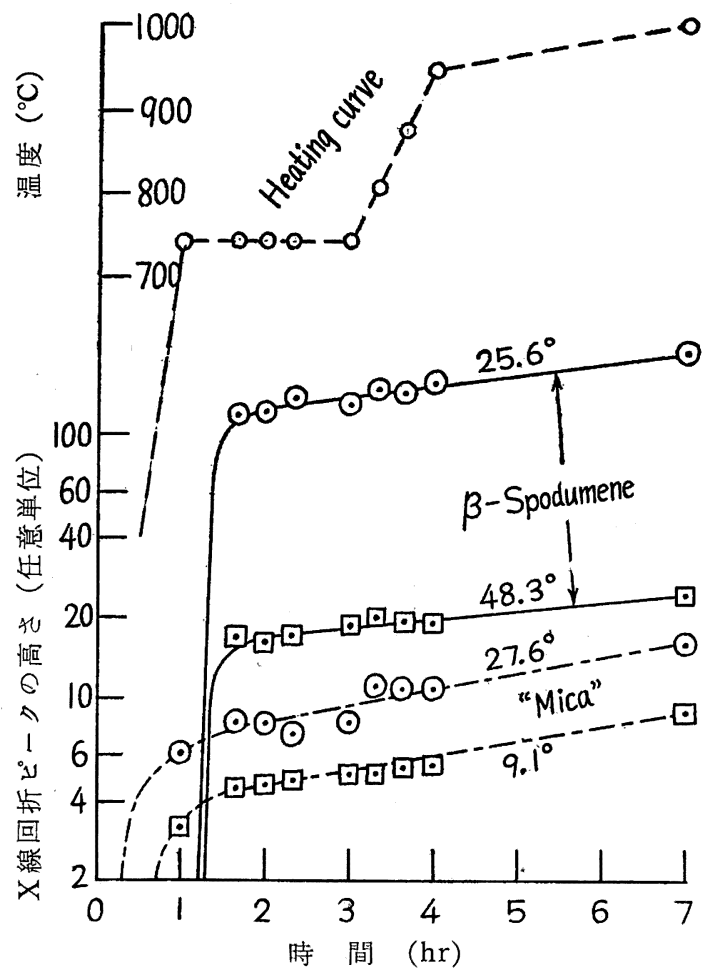

図 3 “Mịca”-Spodumene 系デビトロセラムの結晶析出過程 
形を崩すことなく，さらに高い温度範囲で第 2 熱処理を打こな い，結晶化は完了する。この場合でもな特数\%のガラスは結晶 組織の中残留している。

ここに熱処理を第 1 , 第 2 と区別したのは便宜上の問題で, 原 ガラス試料の㳄化変形が避けられれば, 結晶核生成から結晶化完 了まで門段階で熱処理することも可能である。

熱处理にともな弓結晶の析出過程をみると，たとえば“マイカ” 一スポジウメン系組成のガラスを図 3 のよな加熱曲線にしたが って熱処理しつつ, 順次, 試料を急冷して, それぞれX線解析を おこならと，熱処理の初期を除いてすべての試料に“マイカ” 及ースポジウメンの結晶がみられ，変化しているのは両者の量だけ である7)。しかし，このような単純な過程をとるものは，むしろ 例外で, $\mathrm{Li}_{2} \mathrm{O} \cdot 2 \mathrm{SiO}_{2}-\mathrm{Li}_{2} \mathrm{O} \cdot \mathrm{Al}_{2} \mathrm{O}_{3} \cdot 4 \mathrm{SiO}_{2}$ 系デビトロセラム ${ }^{17) や, ~}$ $\mathrm{Li}_{2} \mathrm{O}-\mathrm{Al}_{2} \mathrm{O}_{3}-\mathrm{SiO}_{2}$ 系フォトセラム ${ }^{2}$ の熱処理過程にみられるよ5 に, 一度析出した $\mathrm{Li}_{2} \mathrm{O} \cdot \mathrm{SiO}_{2}$ の結晶が, 更に高温で残留ガラスと 反応して $\mathrm{Li}_{2} \mathrm{O} \cdot 2 \mathrm{SiO}_{2}$ の結晶に変化したり, 一定の温度に達し てから $\beta$-石英の結晶を析出したりする現象がみられる。非平衡 状態の融液からの結晶の析出である上に, 種々の添加剤の影響が あり，また第 1 次の結晶析出によって場所的な不均一性が加わる ので，かならずしも平衡状態図から直接の解答は得られない。

\section{4 デビトロセラムの性質}

デビトロセラムは一般に $1 \mu$ 程度あるいは，さらにそれより 微細な結晶からなって和り，したがって，その性質は，それを構 成する結晶それ自身の性質と結晶組織とに依存している。デビト ロセラムについて，もっとも興味ある性質の一つである熱的特性 については, 現在のところ, 軟化温度は $1200 \sim 1300^{\circ} \mathrm{C}$ 程度のも のが多く，耐熱材料としてかならずしも耐火度が高いとはいえな
表 3 デビトロセラムの熱膨張係数

\begin{tabular}{|c|c|}
\hline 武 料 名 & $\begin{array}{c}\text { 熱溦張係数 } \\
\left(\times 10^{-7}\right)\end{array}$ \\
\hline パイロセラム 860518) & 14 \\
\hline パイロセラム 860818) & $2 \sim 3$ \\
\hline パイロセラム 960818) & 7 \\
\hline ガラスセラム $\left.\mathrm{Pt}-\mathrm{Mg}^{10}\right)$ & 40 \\
\hline ガラスセラム $Z Z n^{1 \theta)}$ & 5 \\
\hline デビトロセラム DV-217) & $2 \sim 3$ \\
\hline デビトロセラム $\mathrm{M}_{50} \mathrm{~S}_{50}{ }^{7)}$ & 49 \\
\hline デビトロセラム12) & -4.2 \\
\hline
\end{tabular}

いが，熱膨張係数は 10-7 ないしは負の値 にまでおよんでいて， その特徵はむしろすぐ れた耐熱衝撃性にあ る。その一例を表 3 に かかげる。ここに引用 されたデビトロセラム
に含まれる主要な結晶には, $\beta$-ユークリプタイト, $\beta$-石英, $\beta$ スポジゥメンなどがあり，それらの熱膨張係数はそれぞれ負また

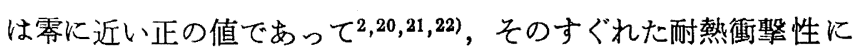
寄与している。

デビトロセラムの他の重要な性質としての力学的特性のろち, 機械的強度に関して，とくに単位重量当りの破断強度の值は一般 の金属材料を上まわるので，さきの耐熱性，耐熱衝撃性と組み合 せて，航空用機材としての広い用途が考えられる。またデビトロ セラムの結晶組織と強度の関係については, すでに田代のくわし い解説 ${ }^{19)}$ があるので省略し，ここでは，その表面硬度と強度との 関係について触れるにとどめる。

渡辺 ${ }^{23)}$ は $\mathrm{K}_{2} \mathrm{O}-\mathrm{Li}_{2} \mathrm{O}-\mathrm{Al}_{2} \mathrm{O}_{3}-\mathrm{SiO}_{2}$ 系の基礎組成に対し, 核生 成剂として銀を，また補助剤として酸化セリウム，酸化スズを添 加したガラス試料を用い，これに図４のような各段階の熱処理を 与えたのち，一群の試料はそのまま，他の群の試料はサンドブラ スト処理で表面に加傷して，それぞれの曲げ強度を測定して，同
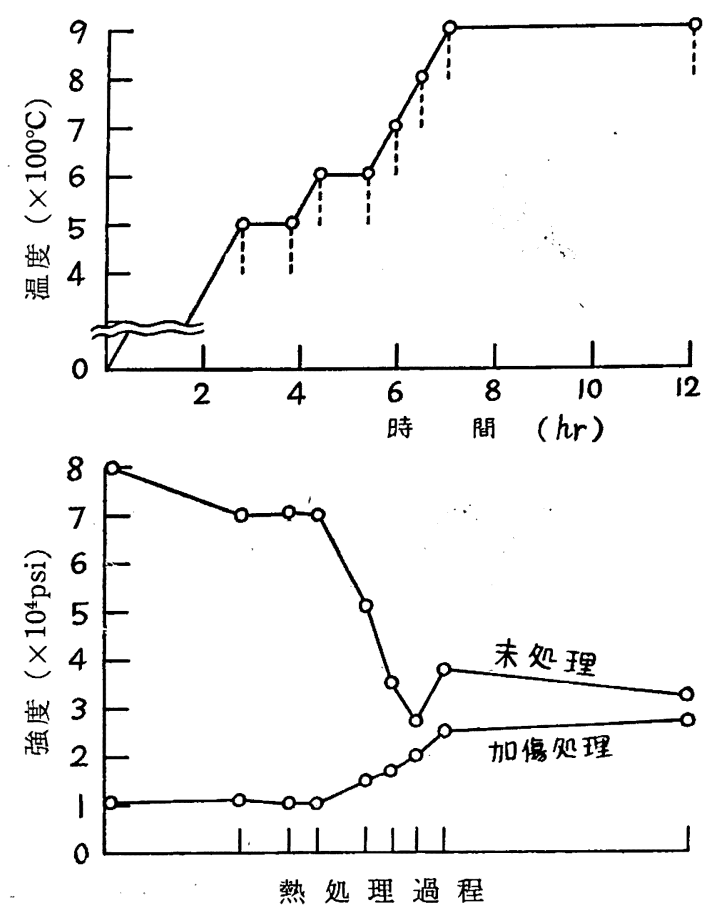

図 4 熱処理による強度変化

図下側に示すような興味ある結果を得た。すなわち結晶化速度は $600^{\circ} \mathrm{C}$ あたりから高温で急速に増大していること。加傷による強 度の低下は, ガラス試料の場合に著しいが，結晶化試料ではその 差が小さいこと。このことはまた，デピトロセラムの表面硬度が きわめて大きいことを意味していると同時に，その表面がガラス の新鮮な表面にくらべて本質的に多くの Flaw を持っていること を示しているとみられる。

その他，デビトロセラムの電気的特性は全般にガラスのそれと 大差ないが，高周波領域では幾分の優位を示している。また化学 的性質としても，一般の酸やアルカリにはかなり強い抵抗性を示 すが，フッ酸に対しては一般のガラスより弱い。これはケイ酸リ シウムの結晶のフッ酸に対する溶解速度がきわめて大きいためで ある（熱的性質以外は表 4 を参照）。

\begin{tabular}{|c|c|c|c|}
\hline & $\begin{array}{l}\text { デビトロ } \\
\text { せラム }\end{array}$ & $\begin{array}{l}\text { パイレッ } \\
\text { クススガタ } \\
\text { ス } 7740\end{array}$ & $\begin{array}{c}\text { 不錆銅 } \\
302\end{array}$ \\
\hline 此 & $2.4 \sim 2.6$ & 2.23 & 7.93 . \\
\hline 気 孔承 & 気 密 & 気 密 & - \\
\hline 単位重量当り破断强度 $\left(\mathrm{psi} \times 10^{-3}\right)$ & $12 \sim 14$ & 4.48 & 10.1 \\
\hline 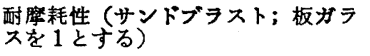 & $20 \sim 30$ & 3.10 & - \\
\hline 誘電率 $\left(25^{\circ} \mathrm{C}\right)\left\{\begin{array}{l}\text { 周波数 } 10^{\circ} \\
\text { 㳊 }\end{array}\right.$ & $\sim 6 \sim$ & $\begin{array}{l}4.6 \\
4.5\end{array}$ & \\
\hline 誘電休損失 $\left(25^{\circ} \mathrm{C}\right)\left\{\begin{array}{l}\text { 周波数 } 10^{\circ} \\
\text { 波 } 10^{10}\end{array}\right.$ & $\begin{array}{l}0.01 \sim 0.03 \\
0.02 \sim 0.05\end{array}$ & & \\
\hline
\end{tabular}

\section{5 むす び}

Devitroceramics は発表されて以来，わずか 3 年を経過したに すぎないが，その特異な加工性と熱的特性などのために，ニュ ウ・セラミックスとして急激な発展をみせ，各国ともに競って研 究をすすめている。しかし特許その他の関係で，その大部分は公 表されずここに引用でさなかったことは残念である。

デビトロセラムはまた, 一般の陶磁器, 耐火物にくらべて, そ の製造方法の点で多量生産方式にのせやすいので, 原料の研究が すすめば，安価な日用品にまで進出することも可能である。しか し，基儊的問題としては，な拉，結晶核生成に関する諸問題，負 
の憉張俰数の説明，また技術的には，タンク宗による溶融の場合 の失透の防止法等, 解決を急ぐ彩案も，また山積している。

一文 献一

1) S. D. Stookey, Ind. Eng. Chem. 45, 115 (1953).

2) S. D. Stookey，目本特許公告 昭 32-5080.

3) S. D. Stookey, Ind. Eng. Chem. 41, 856 (1949).

4) S.D.Stookey, 日本特許公告 昭 33-7543.

5）田代, 和田, 玉城, 化学関係学協会連合秋季研究発表大会 講演 (昭和 34 年 10 月).

6) S. N. Lungu, D. Popescu-Has, Ind. Usoară (Bucharest) 5, 63 (1958); 窘協誌 68, 抄 18 (1960).

7）森谷, 境野, 才野, 遠藤, 窯協誌 68, 44 (1960).

8) 森谷, 境野, 田中, 工化 63, 1129 (1960).

9) 杉浦, 日本特訴公告 昭 26-1121.

10) J.C. Fisher, J. H. Hollomon, D. Turnbull, J. Appl. Phys. 19, 775 (1948).

11) R. D. Maurer, J. Appl. Phys. 29, 1 (1958).
12) 森谷, 境野, 才野, 滰沢, 䇺協誌 68, 103 (1960).

13）田代，作花，䈍協誌 67, 263 (1959).

14) S. D. Stookey, J. Am. Ceram. Soc. 32, 246 (1949).

15) G. E. Rindone, J.Am. Ceram. Soc. 41, 41 (1958).

16）田代, 和田, 玉城，化学関係学協会連合秋季研究発表大会 講演 (昭和 34 年 10 月).

17) 森谷, 境野, 田中, 工化 63, 1129 (1960).

18) Corning Glass 社カタログ.

19) 田代, 科学 29,580 (1959).

20) F. A. Hummel, J. Am. Ceram. Soc. 34, 235 (1951).

21) F. A. Hummel, J. Am. Ceram. Soc. 35, 64 (1952).

22) F. H. Gillery, E. A. Bush, J.Am. Ceram. Soc. 42, 175 (1959).

23) M. Watanabe, R. V. Caporali, R. E. Mould; 電気通信确 究所成果報告第 1316 号 (1959).

24）田代，作花，化学関係学協会連合秋季研究発表大会講 演 (昭和 34 年 10 月).

\section{炭化物の合成（特に WC, TiC を中心として）}

\section{1 緒言}

WC は超硬工具の基本材として，そのまま，または $\mathrm{TiC}$ 等の 炭化物との固溶体の形で使用され, $\mathrm{TiC}$ は超高温耐熱材料, いわ ゆるサーメットの最む適当な原材として重視されている。また一 般に炭化物の多くは耐摩耗, 耐熱, 耐酸化性などの性質にすぐれ ているため, 高温度用炉材, ルッボ用原料, 金属黒鉛などのライ ニング, アークランプなどの電極用として, さらにロケット，ジ エットエンジンなどの然焼室, 噴射ノズル用材質として, その応 用面がひらけてきた。

炭化物の合成法を大別すれば
(1) 融解法
(2) 固相反応法
(3) 固-気相反応法
(4) 沈着法
（5）メンストラム法 (menstrun method)
(6) 融夜電解法

などの方法がある。工業的には主として（2）の方法が行なわれ ているが，（5）の方法もまた複炭化物（WC-TiC）の製造に利 用されている。

\section{2 融 解 法 ${ }^{1)}$}

この方法は Moissan が始めて炭化物を合成したとき使用した 歷史的方法で，極めて高温度を必要とし，温度調節が満足でな く，製品も不純で現在では，あまり利用されていない。

\section{3 固 相 反応法}

現在最も多く工業的に実施されている方法で，金属またはその 化合物々炭素の混合物を還元性雾囲気，むたは真空中で加熱して 金属炭化物をつくる。タングステンと孷素の反応で WC をつく

* 東京工業大学：東京都目黒区大岡山.

** 日立彆作所日立研究所 : 日立市助川町.

\section{久保 輝一郎*・神 力 喜 - ${ }^{* *}$}

る場合，反応雲囲気として，ある分圧の炭化性ガスの存在は炭化を 促進し，したがって，炬の構造いかんによっては反応 $(2 \mathrm{~W}+\mathrm{C}$ $\left.\rightleftharpoons \mathrm{W}_{2} \mathrm{C}, \mathrm{W}+\mathrm{C} \rightleftharpoons \mathrm{WC}\right)$ 経過に相違が括こる2)。表 1 は炉およ び炭化条件の差による最終生成物の相違を示す。水素ガスは高温 度の黒鉛反応管と反応して，炭化水素を生じ，これが炭化反応を 促進する。図1は混合試料中の炭素量をか兄て反応させたとき， 生成物の結合炭素量の変化である ${ }^{3)}$ 。 $5.66 \%$ 以上炭素を混合する と, 結合炭素量は大体 $6.12 \%$ に達し, 雾团気中に生成した炭化 水素の炭化作用のため理論量以下の混合炭素量でも十分炭化がす

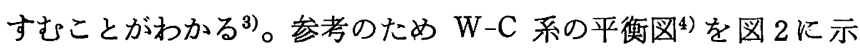

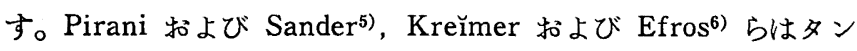
グステン中への炭素の拻散速度を温度の関数として測定し，それ ぞれ拡散の活性化エネルギーとして $59 \mathrm{kcal} / \mathrm{g} \cdot \mathrm{atom}, 112 \mathrm{kcal} / \mathrm{g}$. atom の值をえているが，この両者の間に著しいちがいがある。 さらに後者は拡散がタングステン多結晶体の粒境界にそって括こ らないで，選択的に粒子の自由表面を通して抗こり，最初にWC ができ，WCからWへ炭素が拡散するとき中間周として $\mathrm{W}_{2} \mathrm{C}$ が 生成する。すなわち炭化反応忙 $\mathrm{WC}, \mathrm{W}_{2} \mathrm{C}, \mathrm{W}$ の三つの層を通

表 1 炭化条件と生成物. (W粉末と煤の混合物を試料と する) (F. Skaupy による)

\begin{tabular}{|c|c|c|c|c|c|c|}
\hline \multirow[b]{2}{*}{ 炬の形式と炭化柔件 } & \multicolumn{2}{|c|}{$\mathrm{W}$ 部料 } & \multicolumn{2}{|c|}{$2 \mathrm{~W}+\mathrm{C}$ 試料 } & \multicolumn{2}{|c|}{$\mathrm{W}+\mathrm{C}$ 斌料 } \\
\hline & $\overbrace{\substack{\mathrm{W} \\
\dot{x}-1}}$ & 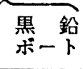 & $\overline{\mathrm{W}}$ & 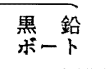 & 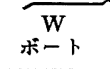 & 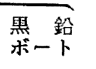 \\
\hline 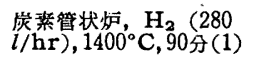 & $\mathrm{W}_{\mathrm{W}} \mathrm{C}$ & $\mathrm{w}_{2} \mathrm{C}$ & $\begin{array}{l}\mathrm{w}_{2} \mathrm{C} \\
\mathrm{C}_{2}\end{array}$ & wc & wc & wc \\
\hline 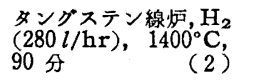 & $\mathrm{w}$ & $\mathrm{w}$ & 少 $\mathrm{W}_{2} \mathrm{C}$ & $\stackrel{\mathrm{W}}{\mathrm{W}_{2} \mathrm{C}}$ & 少 $\mathrm{W}_{2} \mathrm{C}$ & 少 $\mathrm{W}_{2} \mathrm{C}$ \\
\hline 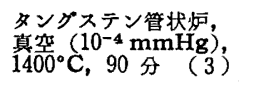 & & & & & $\begin{array}{l}\text { 避離, } \mathrm{C}^{\mathrm{C}} \mathrm{W}_{2} \\
3.4 \%\end{array}$ & , 結合 $\mathrm{C}$ \\
\hline 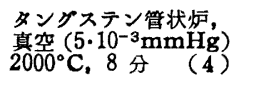 & & & & & 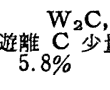 & $\begin{array}{l}\text { WC } \\
\text { 結合 C }\end{array}$ \\
\hline
\end{tabular}

